\title{
Progressive optic neuropathy in congenital glaucoma associated with the Sirsasana yoga posture
}

Daniela S. Monteiro de Barros, MD; Sheila Bazzaz, MD

Wills Eye Institute, Jefferson Medical College

Moataz E. Gheith, MD

Wills Eye Institute, Jefferson Medical College

Ghada A. Siam, MD

Wills Eye Institute, Jefferson Medical College

Marlene R. Moster, MD

Wills Eye Institute, Jefferson Medical College

Follow this and additional works at: https://jdc.jefferson.edu/willsfp

Part of the Ophthalmology Commons

Let us know how access to this document benefits you

\section{Recommended Citation}

Monteiro de Barros, MD; Sheila Bazzaz, MD, Daniela S.; Gheith, MD, Moataz E.; Siam, MD, Ghada A.; and Moster, MD, Marlene R., "Progressive optic neuropathy in congenital glaucoma associated with the Sirsasana yoga posture" (2008). Wills Eye Hospital Papers. Paper 3. https://jdc.jefferson.edu/willsfp/3

This Article is brought to you for free and open access by the Jefferson Digital Commons. The Jefferson Digital Commons is a service of Thomas Jefferson University's Center for Teaching and Learning (CTL). The Commons is a showcase for Jefferson books and journals, peer-reviewed scholarly publications, unique historical collections from the University archives, and teaching tools. The Jefferson Digital Commons allows researchers and interested readers anywhere in the world to learn about and keep up to date with Jefferson scholarship. This article has been accepted for inclusion in Wills Eye Hospital Papers by an authorized administrator of the Jefferson Digital Commons. For more information, please contact: JeffersonDigitalCommons@jefferson.edu. 


\title{
As submitted to: \\ Ophthalmic surgery, lasers \& imaging : the official journal of the International Society for Imaging in the Eye \\ And later published as: \\ "Progressive optic neuropathy in congenital glaucoma associated with the Sirsasana yoga posture" \\ Volume 39, Issue 4, July 2008, Pages 339-340 \\ DOI: 10.3928/15428877-20080701-03
}

\author{
Authors: $\quad$ Daniela S. Monteiro de Barros, MD; Sheila Bazzaz, MD; \\ Moataz E. Gheith, MD; Ghada A. Siam, MD; \\ Marlene R. Moster,MD
}

William and Anna Goldberg Glaucoma Service

Department of Glaucoma

Wills Eye Institute, Jefferson Medical College

840 Walnut Street, Suite 1150

Philadelphia, PA 19107

(215) 928-3342

(215) 928-3285 
Correspondence: Daniela S. Monteiro de Barros, MD

danismb1@yahoo.com.br

The authors have no financial interest related to the article.

\begin{abstract}
The authors describe a case report of progressive glaucomatous neuropathy in a patient with congenital glaucoma who routinely practiced the Sirsasana (Headstand) yoga position for several years. The ophthalmic examination included best-corrected visual acuity, anterior segment examination, indirect ophthalmoscopy, ultrasound pachymetry for central cornea thickness, and intraocular pressure (IOP) before, during and after 5 minutes of headstand yoga posture. The IOP increased significantly during the headdown position. Transient elevation in IOP during yoga exercises may lead to progressive glaucomatous optic neuropathy especially in susceptible patients with congenital glaucoma.
\end{abstract}

\title{
INTRODUCTION
}

Yoga exercises have increased in popularity as a part of an active lifestyle. In addition to physical fitness, yoga has been promoted as an alternative form of therapy for chronic 
illnesses. ${ }^{i}$ With the increasing utilization of these exercises, physicians need to be familiar with the potential side effects in patients with certain medical conditions. ${ }^{\text {ii }}$ Recent studies have described an elevation in intraocular pressure following Sirsasana

(headstand) yoga posture, particularly in patients with glaucomatous optic neuropathy. ${ }^{\text {iii,iv }}$ However, to the best of our knowledge there are no publications describing progressive glaucomatous neuropathy in congenital glaucoma associated with yoga exercises. We report a case of progressive glaucomatous optic neuropathy in a patient with a history of congenital glaucoma who has been performing the Sirsasana headstand posture during yoga exercises for the past 5 years.

\section{CASE REPORT}

A 47-year -old Caucasian female with a history of congenital glaucoma, presented with progressive optic neuropathy and decreased visual acuity in the left eye. She had undergone goniotomy in both eyes in the first year of life and filtration surgery on the left eye 17 years prior to presentation. She recently had cataract extraction on her left eye. Her best corrected visual acuity was 20/20 in the right and 20/80 in the left eye, with a refractive error of $-1.75+2.25$ x 160 and $-2.00+2.75$ x 018, respectively. By Goldmann applanation tonometry, the intraocular pressure was $13 \mathrm{mmHg}$ in the right and $24 \mathrm{mmHg}$ in the left eye. At presentation she was using Alphagan, Betimol, and Travatan in the left eye only. The examination was significant for mild corectopia of the left pupil with a trace afferent pupillary defect and buphthalmos of both eyes. The anterior segment examination was significant for Haab's striae, left greater right and a superior moderately 
elevated avascular bleb in the left eye. The central corneal thickness was $486 \mu$ in the right eye and $539 \mu$ in the left eye, The IOP was unchanged after dilation in both eyes. The optic nerve showed a small healthy cup in the right eye and larger shallow cupping with a full healthy rim in the left eye.

There was evidence of progressive optic neuropathy and visual field defects in the left eye. The IOP was measured with the Tonopen XL before, during and after the headstand position. The patient's IOP rose significant from $13 \mathrm{mmHg}$ before the headstand position to $35 \mathrm{mmHg}$ in the right eye and from $24 \mathrm{mmHg}$ to $50 \mathrm{mmHg}$ in the left eye, during the headstand position. The intraocular pressure after the headstand position decreased to 18 $\mathrm{mmHg}$. The patient would routinely continue this position for ten minutes approximately three times a week.

\section{DISCUSSSION}

Yoga exercises have being advocated as a complementary and alternative medicine technique for various diseases in many countries. ${ }^{\mathrm{V}}$ While these exercises are routinely safe and promote good health, there are risks involved for certain patients. Margo et $\mathrm{l}^{\mathrm{vi}}$ reported that maintaining a headstand position may predispose patients to vascular thrombosis by intermittently increasing conjunctival venous pressure and decreasing venous outflow. Other more recent reports have been described an increase in intraocular pressure associated with yoga exercises. ${ }^{1-4}$ 
In a prospective case observational series, Baskaran et $\mathrm{al}^{\mathrm{iii}}$ demonstrated a uniform 2-fold increase in the IOP during Sirsasana, which was maintained during the posture in all age groups irrespective of the ocular biometry and ultrasound pachymetry. Of significance, all seventy five subjects that were observed did not have a prior diagnosis of glaucoma or any glaucomatous optic neuropathy. Additionally, they concluded that normal patients performing the headstand posture do not need routine ocular examinations to monitor for glaucomatous damage. This study did not address how the elevation and fluctuation of IOP may affect patients with pre-existing glaucomatous optic neuropathy. In a similar presentation as our patient, Gallardo et $\mathrm{al}^{\mathrm{iv}}$ reported a case of a patient with primary open angle glaucoma, splinter disc hemorrhage and progression of glaucomatous optic neuropathy in association with the Sirsasana headstand posture.

It is difficult to make a direct causal relationship between the headstand posture and glaucomatous progression, but in patients with pre-existing glaucomatous optic neuropathy, the dramatic change in intraocular pressure is potentially harmful. The sudden increase in pressure may cause ischemic as well as mechanical pressure related damage to the optic nerve fibers.

The rise in intraocular pressure that occurs during Sirsasana headstand posture has been documented in multiple studies, but further controlled studies in glaucoma patients are needed to make a direct correlation with progression of glaucomatous optic neuropathy. Regardless, it is an important consideration in patients with seemingly controlled IOP, but with worsening optic neuropathy. Additionally, the Sirsasana headstand posture 
should be incorporated into the standard history questionnaire for all patients at risk for glaucoma.

References

${ }^{\mathrm{i}}$ Rice R, Allen RC. Yoga in glaucoma. Am J Ophthalmol. 1985;100(5):738-739.

${ }^{\text {ii }}$ Fahmy JA, Fledelius H. Yoga-induced attacks of acute glaucoma. A case report. Acta Ophthalmol. 1973;51:80-84.

iii Baskaran M, Raman K, Ramani KK, et al. Intraocular pressure changes and ocular biometry during Sirsasana (headstand posture) in yoga practitioners. Ophthalmology. 2006;113:1327-1332.

${ }^{\text {iv }}$ Gallardo MJ, Agarwal N, Cavanagh HD, Whitson JT. Progression of glaucoma associated with the Sirsasana (headstand) yoga posture. Advances in therapy. 2006;23:921-925.

${ }^{\vee}$ Singh V, Raidoo DM, Harries CS. The prevalence, patterns of usage and people's attitude towards complementary and alternative medicine (CAM) among the Indian 
community in Chatsworth, South Africa. BMC Complement Altern Med [serial online] 2004;4:3.

${ }^{\text {vi }}$ Margo CE, Rowda J, Barletta J. Bilateral conjunctival varix thromboses associated with habitual headstanding. Am J Ophthalmol. 1992;113(6)726-727. 